\title{
Behaviour of boiler steel exposed to combustion gases containing bromide and chloride additives
}

\author{
Vered Atiya Zuckerman ${ }^{1}$, Rinat Ittah ${ }^{1}$, Mira Freiberg Bergstein ${ }^{1}$, David Itzhak ${ }^{2}$ \\ ${ }^{1}$ ICL Industrial Products Ltd, Beer Sheva, Israel \\ ${ }^{2}$ Materials Engineering Department Ben Gurion University of the Negev, Beer Sheva, Israel \\ Email address: \\ atiyav@icl-ip.com (V. A.Zuckerman), freibergm@icl-ip.com (M. Freiberg)
}

\section{To cite this article:}

Vered Atiya Zuckerman, Rinat Ittah, Mira Freiberg Bergstein, David Itzhak. Behaviour of Boiler Steel Exposed to Combustion Gases Containing Bromide and Chloride Additives. International Journal of Energy and Power Engineering. Vol. 3, No. 4, 2014 , pp. $162-167$. doi: $10.11648 /$ j.ijepe.20140304.11

\begin{abstract}
Mercury emissions from coal-fired power plants need to be reduced. In a coal-fired power plant, mercury enters the system primarily with the coal, and exits the system as bound particle compounds, soluble mercury or vapor-phase mercury. Oxidized mercury is effectively removed in wet flue gas desulfurization scrubbers - WFGD.one of the options for enhancing the process of mercury absorption is adding oxidizing agents such as bromide/bromine or chloride/chlorine. The present work describes simulation tests performed in order to evaluate the effect of bromide/chloride additions on the behavior of various steels under a combustion environment in a diesel fed steam boiler. The tested samples A209-T1A, A213-T11, A213-T22 and AISI 1020 were exposed at two locations in the boiler system: inside the flame chamber near the wall and in the middle of the stack at a temperature of $250-300^{\circ} \mathrm{C}$ for 3 months. XRD and SEM techniques were used to analyze and to inspect the crystallographic structure. The results clearly show that high temperature interaction between the metal surface and the fire combustion products lead to the deposition of a protective layer composed mainly of $\mathrm{CaSO}_{4}, \mathrm{FeSO}_{4}$ and $\mathrm{Fe}_{3} \mathrm{O}_{4}$. Negligible weight loss was detected in all the tested cases. No harmful effect was detected in the presence of bromide, added as $\mathrm{CaBr}_{2}$, or chloride, added as $\mathrm{CaCl}_{2}$, to diesel fuel, up to a level of $1000 \mathrm{ppm}$.
\end{abstract}

Keywords: Mercury Removal, Bromine, Steam Boiler Steel, Power Station, High Temperature Corrosion, Diffusion Barrier

\section{Introduction}

Mercury is a well-known hazardous material that contaminates the atmosphere and the living environment, and leads to health problems for both humans and animal species. The concerns over bioaccumulation of mercury in tissues of various organisms have led to new regulations to limit mercury emissions from coal-fired generators in the United States, Canada and other countries around the globe [1].

Coal used as fuel in power generation contains mercury and represents a significant contributor of emissions to the atmosphere, although the combustion gases are treated by WFGD or other scrubbing techniques. It has been estimated that US coal-fired power plants currently emit approximately 48 tons of mercury a year [2].

Mercury is present in flue gas in various forms and the form most easily treated and removed is the oxidized mercury ion $\mathrm{Hg}^{+2}$ [2-4]. The oxidized form is easier to remove due to its solubility in water media under alkaline conditions created by the use of calcite rock $-\mathrm{CaCO}_{3}$, in the WFGD. The elemental mercury is insoluble in water therefore it is not easily removed by wet scrubbers [5].

Several methods to oxidize the elemental mercury in flue gas were investigated, in order to improve mercury removal by wet scrubbers [6,]. Halogens, in general have been proven effective in mercury oxidation in coal flue gas environments. From the halogen group chlorides and bromide are mainly used.

A process based on bromide mineral aqueous solution such as $\mathrm{CaBr}_{2}$ enhances mercury removal as was reported elsewhere [8-11]. It is suggested that bromine is more effective in the oxidation of mercury in flue gases, as compared to chlorine. This effectiveness is related to the high selectivity of bromine versus $\mathrm{SO}_{2}$ [12]. As compared to bromine the chlorine is much more effective reacting with the $\mathrm{SO}_{2}$, the concentration of which is much larger than that of the mercury and therefore rapidly consumed, 
before reacting with the mercury. On the other hand, the bromine is not rapidly consumed and remains to react with the mercury according to the following oxidizing reaction:

$$
\mathrm{Hg}+\mathrm{Br}_{2} \rightarrow \mathrm{HgBr}_{2}
$$

Free bromine is produced at high temperature from the bromide added to the fuel according to the following path:

$$
\begin{gathered}
\mathrm{CaBr}_{2}+\mathrm{H}_{2} \mathrm{O} \rightarrow \mathrm{CaO}+2 \mathrm{HBr} \\
2 \mathrm{HBr}+1 / 2 \mathrm{O}_{2} \rightarrow \mathrm{H}_{2} \mathrm{O}+\mathrm{Br}_{2}
\end{gathered}
$$

Thermodynamic considerations support the idea that bromine is more effective as a mercury oxidizer, as compared to chlorine due to the following Griffin reactions: 1. for chlorine consumption:

$$
\mathrm{SO}_{2}+\mathrm{Cl}_{2}+\mathrm{H}_{2} \mathrm{O} \rightarrow \mathrm{SO}_{3}+2 \mathrm{HCl}
$$

2. for bromine consumption:

$$
\mathrm{SO}_{2}+\mathrm{Br}_{2}+\mathrm{H}_{2} \mathrm{O} \rightarrow \mathrm{SO}_{3}+2 \mathrm{HBr}
$$

In contrast to chlorine, the bromine Griffin reaction is thermodynamically not favored, at least at temperatures $>$ $100{ }^{\circ} \mathrm{C}$, because the Gibbs free reaction enthalpy of the bromine Griffin reaction is strongly positive, within the whole boiler temperature range. Therefore, $\mathrm{SO}_{2}$ does not consume $\mathrm{Br}_{2}$. This means that most of the added bromine actually reacts with mercury to produce the oxidized ion $\mathrm{Hg}^{+2}[12]$

When we consider using halogen technologies as mercury control methods the potential for accelerated corrosion in boilers has to be taken into account. Free halogens such as $\mathrm{Cl}_{2}$ and $\mathrm{Br}_{2}$ are well known oxidizers that may directly react with the metallic surface of most of the known metallic materials [13]. Chlorine can cause serious corrosion damage in process equipment when the temperature is higher than the melting points of the interaction products or in the case where the temperature is lower than the dew point of water. Several works have been conducted to examine the influence of gaseous $\mathrm{Cl}_{2}$ or $\mathrm{HCl}$ on the corrosion of different alloys [14-18].

The influence of bromine on the behavior of metallic materials in flue gases was not investigated under boiler or coal power plant environments. Bromine is not naturally abundant in coal and this may be a reason that it was neglected until now. It is very difficult to simulate such research in a laboratory and a small scale system could not effectively demonstrate the system parameters. For that reason the simulation was made in the full scale steam boiler at the Bromine Compounds Ltd. Ramat Hovav site.

\section{Experimental Methods}

Boiler steels of types: A209-T1A, A213-T11 and A213-T22 supplied by Metal Samples and mild steel AISI-1020 - prepared in our lab, were exposed to the flue gases in an industrial steam generator in ICL - IP production

\begin{tabular}{|c|c|c|c|c|c|c|c|c|c|c|c|c|}
\hline & $\mathrm{C}$ & $\mathrm{Mn}$ & $\mathrm{P}$ & $\mathrm{S}$ & $\mathrm{Si}$ & $\mathrm{Al}$ & $\mathrm{Cr}$ & Mo & $\mathrm{Ni}$ & $\mathrm{Cu}$ & $\mathrm{V}$ & $\mathrm{Fe}$ \\
\hline AISI 1020 & $0.18-0.23$ & $0.3-0.6$ & 0.04 & 0.05 & $=$ & $=$ & $=$ & $=$ & $=$ & $=$ & $=$ & balance \\
\hline ASME A209-TIA & 0.18 & 0.54 & 0.014 & 0.013 & 0.23 & $=$ & $=$ & 0.48 & $=$ & $=$ & $=$ & balance \\
\hline ASME A213-T11 & 0.08 & 0.49 & 0.019 & 0.007 & 0.58 & 0.2 & 1.5 & 0.52 & 0.04 & 0.06 & 0.001 & balance \\
\hline ASME A213-T22 & 0.09 & 0.49 & 0.018 & 0.014 & 0.21 & 0.025 & 2.09 & 0.92 & 0.07 & 0.09 & 0.002 & balance \\
\hline
\end{tabular}
plant in Ramat Hovav site, located in the south of Israel, in the desert part. The composition of the metals is presented in Table 1.

Table 1. Element composition of the tested samples

It should be noted that the boiler steels alloyed with metallic elements such as $\mathrm{Cr}, \mathrm{Mo}, \mathrm{Ni}, \mathrm{Cu}$ and $\mathrm{V}$. These alloying elements improve mechanical properties at elevated temperatures and also improve oxidation resistant and thermal fatigue behavior.
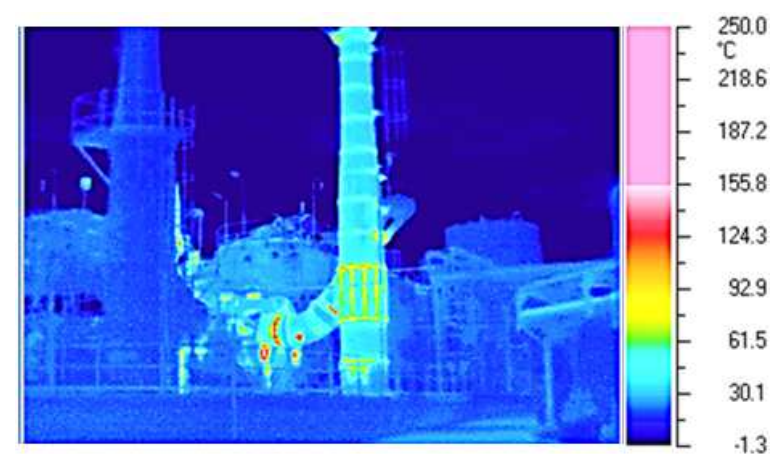

Figure 1. Thermal photograph of the steam generator in ICL-IP production site in Ramat Hovav
The metal samples were thermally annealed at a temperature between $704^{\circ} \mathrm{C}$ and $927^{\circ} \mathrm{C}$. The samples were polished up to 120 grit using $\mathrm{SiC}$ polishing paper and prior to exposure, the samples were washed with deionized water and dried with acetone. Exposure tests were carried out in a diesel fuel steam boiler system in Ramat Hovav site as presented in Fig.1. This is the main steam generator in the central industrial production site of ICL. The outside temperature mapping was made by thermal camera. Typical view could be seen in Fig. 1. The picture shows hot spots along the stack and the outside temperature around $60^{\circ} \mathrm{C}$.

The samples were located at two different places in the boiler system:

-Inside the flame chamber, near the wall where the temperature was about $200^{\circ} \mathrm{C}$.

-In the middle of the stack, near the wall where the temperature was about $130^{\circ} \mathrm{C}$.

The samples were exposed for a period of 3 months. 2 coupons of each metal were exposed at each location. The 
fuel was analyzed using ICP for chloride, bromide and sulfur. The content of contaminants was found to be $\mathrm{Cl}^{-}, \mathrm{Br}^{-}$less than $20 \mathrm{ppm}$ and sulfur $0.8 \mathrm{wt} \%$. The boiler was fed with diesel fuel doped with $52 \mathrm{wt} \% \mathrm{CaBr}_{2}$ solution as a source of bromine and $20.5 \mathrm{wt} \% \mathrm{CaCl}_{2}$ solution as a source of chlorine.

The solutions were fed to the fuel pipe by a dosing pump. The feeding protocol was:

-Fuel consumption: $500 \mathrm{Kg} / \mathrm{h}$ heavy diesel fuel oil in continuous mode.

-Bromide : $71 \mathrm{ml}$ of $52 \mathrm{wt} \% \mathrm{CaBr}_{2}$ solution per hour in order to reach $100 \mathrm{ppm} \mathrm{Br}$ and $710 \mathrm{ml}$ per hour in order to reach $1000 \mathrm{ppm} \mathrm{Br}$.

-Chloride: $320 \mathrm{ml}$ of $20.52 \% \mathrm{CaCl}_{2}$ solution per hour to reach a level of $100 \mathrm{ppm} \mathrm{Cl}$ and $3200 \mathrm{ml}$ per hour in order to reach a level of $1000 \mathrm{ppm} \mathrm{Cl}$.

-Bromide and Chloride: $710 \mathrm{ml}$ of $52 \mathrm{wt} \% \mathrm{CaBr}_{2}$ solution and $3200 \mathrm{ml}$ of $20.52 \% \mathrm{CaCl}_{2}$ per hour to reach a level of $1000 \mathrm{ppm}$ each, and $71 \mathrm{ml}$ of $52 \mathrm{wt} \% \mathrm{CaBr}_{2}$ solution and 320 $\mathrm{ml}$ of $20.52 \% \mathrm{CaCl}_{2}$ per hour to reach a level of $100 \mathrm{ppm}$ each.

-Base line - blank run: reference run was made with pure fuel oil with no additives.

After the exposure tests the samples were visually inspected, cleaned and weighed for corrosion rate measurement. The morphology and composition of the surface products as well as the crystallographic structure were determined using scanning electron microscopy SEM and X-ray diffraction.

\section{Results and Discussion}

All the exposed metal samples were affected by the flue gases atmosphere and showed an increase in weight. All the samples were covered with a dark adhesive layer as shown in Fig 2. The environment inside the chamber acted as a vapor deposition reactor. The main effect was scale deposition as it can be seen in Figs 2, b and c.

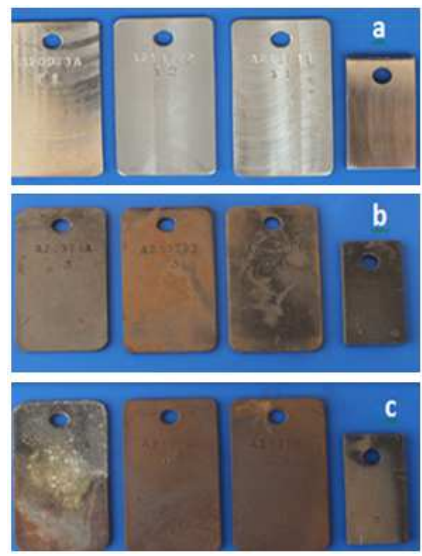

Figure 2. The tested samples obtained after exposure to 1000 ppm bromides and chlorides, $a$ : reference, $b:$ stack, $c$ : flame chamber

Scale formation is a typical behavior of resistant metals exposed to high temperature environment under dry oxidation conditions. An adhesive layer can be formed as a result of the chemical interaction between the metal surface and the stream of the flue gases that passes near the surface of the metallic samples. The layer formed on the surface was composed of two types of materials. The first type, in an atmosphere containing oxygen, is mainly composed of oxides such as magnetite $\mathrm{Fe}_{3} \mathrm{O}_{4}$ and hematite $\mathrm{Fe}_{2} \mathrm{O}_{3}$, and depends on the activity of the oxygen $[19,20]$. High activity of oxygen leads to the formation of $\mathrm{Fe}^{+3}$ ions while moderate activity leads to the formation of the mixed $\mathrm{Fe}^{+2} / \mathrm{Fe}^{+3}$ ions ,meaning magnetite. When we consider this we can understand the findings of ferrous alloys exposed to oxidative atmosphere at elevated temperature.

Weight gain and corrosion rate of the metallic samples are presented in Tab. 2. It is clearly demonstrated that all the samples were not significantly affected. All the samples show weight gain with no loss of wall thickness. This is related to the diffusion barrier formed on the surface as a result of two parameters. The first is the oxidation under dry conditions and the second is the deposition of crystalline gypsum $\mathrm{CaSO}_{4}$ as will be discussed.

XRD findings of all the tested samples after exposure are presented in table 3 . As it is clearly seen the calcium additive encourages the formation of sulfates as a solid deposit on the metallic surface. This phenomenon was found on all the tested samples regardless of the type of the metal or the location. The formation of a diffusion barrier on the exposed metallic surface leads to very low corrosion rates in all the cases.

Table 2. weight gain and corrosion rate after 3 month of exposure

\begin{tabular}{cccc}
\hline Alloy & Location & $\begin{array}{c}\text { Weight gain } \\
{[\mathbf{m g} / \mathbf{c m} 2]^{*}}\end{array}$ & $\begin{array}{c}\text { Corrosion rate } \\
{[\mathbf{m p y}]}\end{array}$ \\
\hline \multirow{2}{*}{1020} & Flame chamber & 3.7 & $\mathrm{Nil}$ \\
& Stack & 2.8 & $\mathrm{Nil}$ \\
A209-T1A & Flame chamber & 2.6 & $\mathrm{Nil}$ \\
& Stack & 3.3 & $\mathrm{Nil}$ \\
A213T22 & Flame chamber & 4.2 & $\mathrm{Nil}$ \\
& Stack & 1.7 & $\mathrm{Nil}$ \\
\multirow{2}{*}{ A213T11 } & Flame chamber & 1.5 & $\mathrm{Nil}$ \\
& Stack & 1.5 & $\mathrm{Nil}$ \\
\hline
\end{tabular}

With no additives this barrier is composed of iron oxides and with calcium additive it is mainly composed of sulfates such as gypsum. In most of the cases, under oxidative atmosphere, the upper oxide layer, produced on ferrous metal, at elevated temperature, is usually composed of hematite- $\mathrm{Fe}_{2} \mathrm{O}_{3}$. When we penetrate into the layer the oxygen activity starts to decrease, leading to the formation of magnetite $\mathrm{Fe}_{3} \mathrm{O}_{4}$, as a subscale. When we enter even deeper and reach the virgin metal we find the inner sub layer adjacent to the metallic matrix composed mainly of wustite -iron oxide of the $\mathrm{FeO}$ form.

The sulfates phases found on the metallic surface can be considered as vapor deposited products. The flue gases contain raw materials that may react to produce solid products as deposits, for example when calcium and sulfate exist in the gas phase, gypsum as $\mathrm{CaSO}_{4}$ or $\mathrm{CaSO}_{4} 0.5 \mathrm{H}_{2} \mathrm{O}$ may be formed and this may create a solid deposit that acts 
as a diffusion barrier between the gas phase and the metallic surface. This diffusion barrier is a protective layer against further attack of the metallic surface. Diffusion barrier is a crucial parameter in the protection of metals against hostile environments at elevated temperature. In our case the additions of $\mathrm{CaBr}_{2}$ promoted the formation of gypsum on the metallic surface, as a solid diffusion barrier, and therefore built a protective layer against further oxidation.

Table 3. XRD findings of phases found on the metal surface

\begin{tabular}{|c|c|c|c|}
\hline steel & location & Exposed 1000ppm $\mathrm{Cl}^{-}+1000 \mathrm{ppm} \mathrm{Br}^{-}$ & Exposed without additives \\
\hline \multirow{5}{*}{ AISI 1020} & \multirow{3}{*}{ Flame chamber } & \multirow{3}{*}{$\mathrm{CaSO}_{4} * 0.15 \mathrm{H}_{2} \mathrm{O} \mathrm{Fe}_{3} \mathrm{O}_{4} \mathrm{CaSO}_{4}$} & $(\mathrm{FeO}(\mathrm{OH}))$ \\
\hline & & & \\
\hline & & & $\mathrm{Fe}_{3} \mathrm{O}_{4}$ \\
\hline & \multirow[b]{2}{*}{ stack } & \multirow[b]{2}{*}{$\mathrm{CaSO} 4 * 0.15 \mathrm{H} 2 \mathrm{O} \mathrm{Fe}_{3} \mathrm{O}_{4} \mathrm{CaSO}_{4}$} & Goethite $(\mathrm{FeO}(\mathrm{OH}))$ \\
\hline & & & $\mathrm{Fe}_{3} \mathrm{O}_{4}$ \\
\hline \multirow{2}{*}{ ASME T1A } & Flame chamber & $\mathrm{CaSO}_{4}, \mathrm{CaSO}_{4} * 0.15 \mathrm{H}_{2} \mathrm{O} \mathrm{CaO}, \mathrm{Ca}(\mathrm{OH}) 2$ & Goethite $(\mathrm{FeO}(\mathrm{OH}))$ \\
\hline & stack & $\mathrm{CaSO}_{4}, \quad \mathrm{CaO}, \mathrm{Ca}(\mathrm{OH}) 2$ & Iron sulfate hydrate \\
\hline \multirow{3}{*}{ ASME T11 } & \multirow[b]{2}{*}{ Flame chamber } & \multirow[b]{2}{*}{$\mathrm{FeSO}_{4} * 7 \mathrm{H}_{2} \mathrm{O} \mathrm{CaSO} 4$} & Iron sulfate hydrate Goethite $(\mathrm{FeO}(\mathrm{OH}))$ \\
\hline & & & $\mathrm{Fe} 3 \mathrm{O} 4$ \\
\hline & stack & FeSO $4 * 7 \mathrm{H} 2 \mathrm{O} \mathrm{CaSO} 4$ & (Rozenite) $\mathrm{FeSO}_{4}\left(\mathrm{H}_{2} \mathrm{O}\right) 4$ \\
\hline \multirow{2}{*}{ ASME T22 } & Flame chamber & $\mathrm{CaSO} 4 * 0.5 \mathrm{H}_{2} \mathrm{O} \mathrm{CaSO}{ }_{4}$ & Goethite $(\mathrm{FeO}(\mathrm{OH}))$ \\
\hline & stack & $\mathrm{CaSO}_{4} * 7 \mathrm{H}_{2} \mathrm{O} \mathrm{CaSO} \mathrm{CaO}_{4} \quad \mathrm{CaO}$ & Goethite $(\mathrm{FeO}(\mathrm{OH})) \mathrm{Fe}_{3} \mathrm{O}_{4}$ \\
\hline
\end{tabular}

The color of the deposited layer depends on composition and microstructure. Dark to gray or black color in ferrous alloys may be attributed to the formation of magnetite $\mathrm{Fe}_{3} \mathrm{O}_{4}$. When oxidation of iron takes place the intermediate layer is usually composed of magnetite and the red color of hematite starts to appear when the oxygen activity is high, which is the upper subscale of the oxide. All the exposed samples were obtained with dark scale which indicated moderate conditions in terms of oxygen activity. EDS analysis, given in Fig. 3 presents typical behavior when calcium brine is added to the flue gas, significant peaks related to calcium and sulfur appears. With no additive only small peak of sulfur could be detected. The layer of gypsum deposited on the surface masks the oxides subscale and leads to small peaks of oxides and the base metal. This behavior was found in all the other alloys tested.

Typical morphology of the exposed metallic surfaces is given in Fig. 4. Irregular continuous micro crystalline structure can be observed on the entire exposed sample. Coarser microcrystalline morphology could be seen on the samples located near the flame chamber. This phenomenon is attributed to the enhanced crystallization process that takes place at higher temperature, characterizing the flame chamber zone. Grain growth process is thermally activated and at higher temperature, we can detect coarse grains as was observed [21].

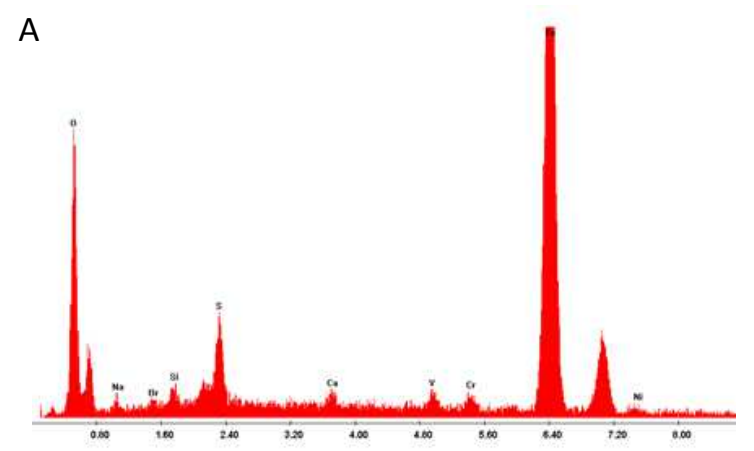

B

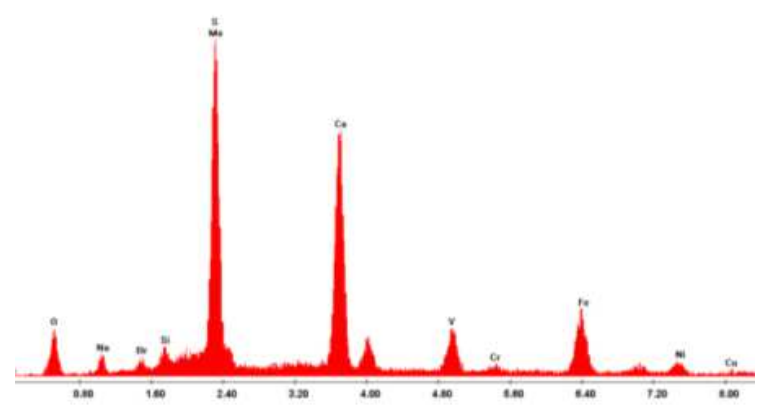

A- No additive,

B- 1000ppm $\mathrm{CaCl}_{2} / \mathrm{CaBr}_{2}$

Figure 3. EDS analysis of exposed 1020 steel surfaces. 

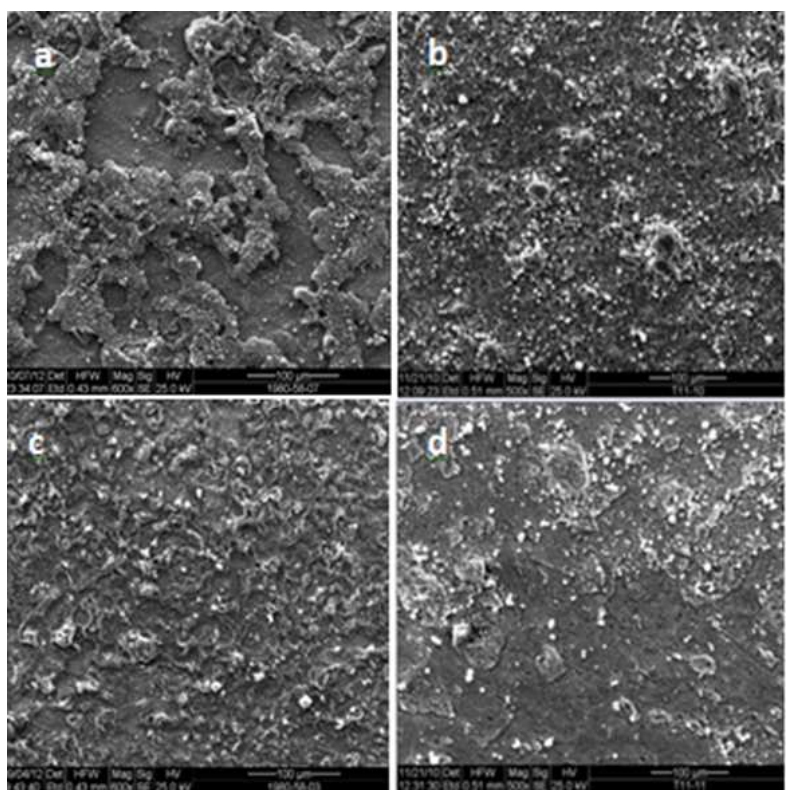

Flame chamber: a- no additive, b- $1000 \mathrm{ppm} \mathrm{CaCl}_{2} / \mathrm{CaBr}_{2}$

Stack: c- no additive, d- $1000 \mathrm{ppm} \mathrm{CaCl}_{2} / \mathrm{CaBr}_{2}$

Figure 4. SEM micrographs of the exposed TIA samples

Our findings demonstrate good resistance of the tested alloys to the environment of the flue gas in the temperature range of $130^{\circ} \mathrm{C}-200^{\circ} \mathrm{C}$ under dry conditions. The diffusion barrier based on the vapor deposited gypsum and the magnetite layer, effectively protect the metallic surface against further corrosion attack. The use of $\mathrm{CaBr}_{2} / \mathrm{CaCl}_{2}$ did not affect negatively the system in terms of corrosion damage; hence the use of calcium additive is important when we consider using $\mathrm{CaBr}_{2}$ as a source of bromide in mercury removal technology.

\section{Conclusions}

1. The findings show very light corrosion damage caused at elevated temperature under dry conditions. Weight loss was not recorded and only weight gain was measured.

2. Addition of $\mathrm{CaBr}_{2} / \mathrm{CaCl}_{2}$ to the fuel up to a level of $1000 \mathrm{ppm}$ does not affect negatively the behavior of the tested metals. This is related to the diffusion barrier formed on the surface during exposure to the flue gas under dry conditions

3. As a result of the exposure to the steam boiler flue gas environment, all the tested metals behaved similarly indicating mutual factor determining the results. The main parameter affecting the results is the deposition of a protective layer creating a diffusion barrier which inhibits the corrosion process. When calcium salts were added as chloride or bromide the deposited layers were composed of various crystalline main phases such as: $\mathrm{CaSO}_{4} 0.15 \mathrm{H}_{2} \mathrm{O}, \mathrm{Fe}_{3} \mathrm{O}_{4}, \mathrm{CaSO}_{4}, \mathrm{CaO}$, 4.

\section{References}

[1] Schoeny R.Hassett- Sipple B, Swartout J. "Mercury study report to congress", Us environmental Protection Agency, Office of air quality planning and standards, Technical report, 1997, EPA- 452/R-97-007.

[2] Feeley, Brickett LA, O'Palko BA, Murphy JT, "Field testing of mercuary control technologies for coal-fired power plants", DOE\NETL Mercury R\&D Pogram Review, May 2005.

[3] Ye Zhuang, Chuanmin Chen, Ron Timple and John Pavlish, "Investigation on bromine corrosion associated with mercury control technologies in coal flue gas", Fuel, vol 88, pp. 1692-1697,2009.

[4] Kellie, Cao Y, Duan Y, et, "Factors affecting mercury speciation in $100 \mathrm{MW}$ coal-fired boiler with low-NOX burners", Energy fuel, vol 19, pp. 800-6, 2005.

[5] Blythe G, Richardson C, Rhudy R. "Pilot evaluation of the catalytic oxidation of mercury for enhanced removal in wet FGD systems". In: Proceedings of the air quality III: mercury, trace elements, and particulate matter conference, Arlington, VA, September, pp. 9-12, 2002.

[6] Mercedes Díaz-Somoano, Sven Unterberger and Klaus R.G. Hein, "Mercury emission control in coal-fired plants: The role of wet scrubbers", Fuel Processing Technology, vol 88 pp. 259-263, 2007.

[7] Galbreath KC, Zygarlicke CJ, Tibbetts JE, Schulz RL, Dunham GE, "Effects of NOx, a- $\mathrm{Fe}_{2} \mathrm{O}_{3}, \mathrm{c}-\mathrm{Fe}_{2} \mathrm{O}_{3}$, and $\mathrm{HCl}$ on mercury transformations in a 7-kW coal combustion system", Fuel Process Technol, vol 86(4),pp. 429-48, 2005.

[8] Liu S, Yan N, Liu Z, Qu Z, et al, "Using bromine gas to enhance mercury removal from flue gas of coal-fired power plants", Environ Sci Technol, vol 41(4), pp. 1405-12, 2007.

[9] Cao Y, Gao Z, Zhu J, Wang Q, Huang Y, Chiu C, et al. "Impacts of halogen additions on mercury oxidation, in a slipstream selective catalyst reduction(SCR), reactor when burning sub-bituminous coal", Environ Sci Technol, vol 42(1), pp.256-61, 2008.

[10] Klaus H Oehr,"Enhanced mercury control in coal- fired power plant. Patent no. US 6,808,692 B2, Oct, 26, 2004.

[11] Vosteen Bernhard, "Process for removing mercury from flue gases”, Patent no. EP 1386655 B1, Feb,4 , 2004.

[12] Bernhard W.Vosteen,Rico Kanefke and Heinz Koser, "Bromine-enhanced Mercury Abatement from Combustion Flue gases Recent Industrial Application and Laboratory Research", VGB PowerTech vol 86, pp 70-75,2006.

[13] Callister W. D., Jr., 2003, "Materials Science and Engineering an Introduction", Sixth Edition, John Wiley \&Sons, lnc.

[14] Huijbregts WMM, Leferink R, "Latest advances in the understanding of acid dewpoint corrosion and stress corrosion cracking in combustion gas condensates", Anti-Corros Methods Mater, vol 51(3), pp. 173-88, 2004.

[15] Persson K, Brostroem M, Carlsson J, "High temperature corrosion in a 65-MW waste-to-energy plant", Fuel Process Technol, vol 88(11-12), pp. 1178-1182, 2007. 
[16] Nielsen HP, Frandsen FJ, Dam-Johansen K, Baxter LL, "The implications of chlorine-associated corrosion on the operation of biomass-fired boilers", Progress Energy Combust Sci, vol 26(3), pp. 283-298,2000.

[17] Spiegel M, Zahs Aand Grabke HJ, "Fundamental aspects of chlorine-induced corrosion in power plants", Mater High Temp, vol 20(2), pp.153-159, 2003.

[18] Zahs A, Spiegel M, Grabke HJ, "Chloridation and oxidation of iron, chromium, nickel and their alloys in chloridizing and oxidizing atmospheres at $400-700^{\circ} \mathrm{C}$ ", Corros Sci , vol 42(6), pp.1093-122. 2000.
[19] Alam Matthews, "Magnetite formation by the reduction of hematite with iron under hydrothermal conditions", American Mineralogist, vol 61 , pp. 927-932, 1976.

[20] W.W Smeltzer. "The kinetics of wustite scale formation on iron”, Acta Metallurgica, vol 8 (6), pp 377-383, 1960.

[21] Erik Khzouz, "Grain Growth Kinetics in Steels", A Major Qualifying Project Report Submitted to the Faculty of the WORCESTER POLYTECHNIC INSTITUTE Project Number: RDS 21381. 2011. 